\title{
Pemanfaatan Media Jam Sudut dalam Pembelajaran SD
}

\author{
Utilization of Angular Clock Media in Elementary Learning
}

\author{
Laelia Nurpratiwiningsih*1, Prasetyo Yuli Kurniawan², Nova Indriyani ${ }^{3}$, Yunika \\ Purwanti ${ }^{4}$ \\ *1,3 Program Studi Pendidikan Guru Sekolah Dasar, Fakultas Keguruan dan Ilmu Pendidikan, \\ Universitas Muhadi Setiabudi, Indonesia \\ ${ }_{2}^{2}$ Program Studi Bahasa dan Sastra Indonesia, Fakultas Keguruan dan Ilmu Pendidikan, Universitas \\ Muhadi Setiabudi, Indonesia \\ ${ }^{4}$ Program Studi Ilmu dan Teknologi Pangan, Fakultas Sains dan Teknologi Pangan, Universitas Muhadi \\ Setiabudi, Indonesia \\ e-mail:*laelia.np89@gmail.com, ${ }^{2}$ prasetyoyulikurniawan@gmail.com, \\ ${ }^{3}$ novaindiryani@gmail.com, ${ }^{4} y u n i k a @ u m u s . a c . i d$
}

\begin{abstract}
Abstrak
Permasalahan yang muncul di SD Negeri 3 Pasarbatang adalah minat belajar masih rendah dan hasil belajar peserta didik di bawah KKM. Oleh karena itu, kami berinisiatif untuk melakukan kegiatan PKM melalui pemanfaatan media jam sudut dalam pembelajaran SD. Peran media pembelajaran sangat penting dalam pembelajaran dan dibutuhkan oleh guru dalam pembelajarannya. Media pembelajaran dibutuhkan untuk meningkatkan kreativitas guru. Sasaran dalam kegiatan ini adalah peserta didik kelas V. Kegiatan dilakukan di SD Negeri 3 Pasarbatang dengan cara memberikan pengajaran menggunakan media jam dinding. Media ini disesuaikan dengan tema di kelas $V$. Hal ini dikarenakan pada kelas tersebut belum memenuhi dalam pembelajaran. Kegiatan dilakukan dengan maksud agar media jam sudut dapat dimanfaatkan dalam pembelajaran, sehingga hasil pembelajaran dapat meningkat dan adanya perubahan pengetahuan, sikap, keterampilan dan tingkah laku bagi peserta didik dalam belajar.
\end{abstract}

Kata kunci-Pemanfaatan, Media Jam Sudut, Pembelajaran SD.

\begin{abstract}
The problem that arises in SD Negeri 3 Pasarbatang is that learning interest is still low and the learning outcomes of learners under KKM. Therefore, we took the initiative to conduct PKM activities through the use of corner clock media in elementary school learning. The role of learning media is very important in learning and is needed by teachers in their learning. Learning media is needed to increase the creativity of teachers. The target in this activity is class V students. Activities are carried out in SD Negeri 3 Pasarbatang by providing teaching using wall clock media. This media is adapted to the theme in class $V$. This is because the class has not met in learning. Activities are carried out with the intention that the corner clock media can be utilized in learning, so that learning outcomes can increase and there are changes in knowledge, attitudes, skills and behavior for learners in learning.
\end{abstract}

Keyword-Utilization, Media Clock Angle, Elementary Learning.

\section{PENDAHULUAN}

Permasalahan dalam kegiatan pengabdian masyarakat ini adalah minat belajar masih rendah dan hasil belajar peserta didik di bawah KKM. Peserta didik diarahkan pada kelas V SD Negeri Pasarbatang 03. Minat belajar akan berpengaruh terhadap hasil belajar peserta didik. Apabila minat belajar peserta didik kurang, maka akan berpengaruh terhadap pembelajarannya. Kurangnya minat belajar peserta didik perlu dikaji permasalahannya. Berkaitan dengan hal

Submitted: bulan Juli 2021, Accepted: bulan Agustus 2021, Published: Agustus 2021

ISSN 2746-6345 (media online) 
tersebut pembelajaran matematika, dianggap sulit oleh peserta didik. Padahal pembelajaran tersebut dapat digunakan dan dimanfaatkan dalam kehidupan sehari-hari. Selain itu, media pembelajaran yang digunakan dalam pembelajaran juga sangat minim, sehingga dalam pembelajaran kurang menarik minat peserta didik dalam belajar.

Tujuan dari pengabdian kepada masyarakat adalah adanya peningkatan hasil belajar peserta didik dalam pembelajaran. Media yang digunakan lebih bervariatif dan inovatif. Guru lebih banyak mengeksplor kemampuan dalam pembelajaran. Kreativitas guru dalam memberikan pengajaran akan berpengaruh terhadap hasil belajar peserta didik. Media belajar yang digunakan harus inovatif dan kekinian. Sehingga peserta didik mudah dalam menggubahkan dan mengikuti dalam pemberian materi pembelajaran.

Media pembelajaran dapat dimanfaatkan dalam menambahkan materi pembelajaran. (Kurniawan et al., 2021) Media pembelajaran dapat dimanfaatkan dalam pembelajaran menulis. Media yang digunakan sederhana dengan menggunakan gambar. Dengan adanya gambar dapat meningkatkan pembelajaran peserta didik. Dengan adanya media tersebut dapat memberikan pemahaman dan keterampilan bagi peserta didik. Berkaitan dengan hal tersebut, media yang sederhana juga dapat dimanfaatkan untuk memecahkan masalah di kelas,

Solusi dalam memecahkan masalah tersebut adalah dengan adanya kegiatan sosialisasi dalam pemanfaatan media jam sudut dalam pembelajaran SD. Media sudut jam disajikan untuk mengukur kemampuan peserta didik. Media sudut jam dibuat semenarik mungkin, agar peserta didik mudah dalam memahami materi yang diberikan. Media yang digunakan dapat dikatakan sederhana, namun dapat memberikan ketertarikan bagi peserta didik dalam belajar.

Kajian teoritik dalam menyelesaikan permasalahan tersebut, antara lain; pemanfaatan, media jam sudut, dan pembelajaran SD. Pemanfaatan adalah suatu kegiatan proses yang menjadikan sesuatu menjadi lebih bermanfaat. Sedangkan media pembelajaan adalah saran untuk meningkatkan kegiatan proses belajar mengajar. Manfaat media pembelajaran antara lain poses pembelajaran akan lebih menarik, bahan pengajaran lebih bermakna, metode mengajar lebih bervaariasi dan kegiatan lebih menarik. Bentuk media pembelajaran bermacam-macam. Salah satu media jam sudut yang dapat digunakan dalam memecahkan masalah ini adalah media jam sudut. Media jam sudut adalah

Manfaat media jam sudut untuk memudahkan guru dalam menjelaskan macam-macam sudut, besar sudut dan cara melukis sudut. Jam dinding dapat dijadikan sebagai penunjuk waktu. Dengan adanya waktu maka dapat diukur kebutuhan yang akan digunakan. Selain itu, jam dinding juga dapat berfungsi sebagai penghias dinding. Jam dinding dengan bentuk unik akan menjadikan dinding menjadi indah dan enak dipandang (Suharti Kadar, 2020). Dalam penunjukkan jam dapat menunjukan jarak pada satu angka dan setiap sudut dapat menunjukkan angka sampai pada $360^{\circ}$. Putaran tersebut dapat dijadikan patokan dalam sudut jam. Sudut merupakan gagasan yang dipelajari dalam geometri. Dapat dikatakan bahwa sudut adalah gabungan dari dua buah sinar garis titik yang bersekutu. Sudut dapat dikelompokkan menjadi sudut siku-siku $\left(90^{\circ}\right.$.), sudut lancip $\left(90^{\circ}\right)$ dan sudut tumpul $\left(180^{\circ}\right)$.

Media jam sudut dapat dimanfaatkan dalam pembelajaran matematika. Pembelajaran matematika menurut karakteristik peserta didik SD dipengaruhi oleh proses belajar yang ditempuhnya. Guru dapat menjadi fasilitator, pembimibing, narasumber dan pemberi informasi terkait dengan pembelajaran. Perkembangan peserta didik dapat meliputi mengembangkan konsep dalam kehidupan sehari-hari, mengembangkan kata nilai, dan mengembangkan sikap terhadap kelompok dan institusi sosial.

Media pembelajaran dapat memberikan efek pada hasil belajar. Hasil belajar merupakan proses perubahan dari pengalaman sebelumnya dan menimbulkan adanya perubahan baru bagi peserta didik. Dengan adanya media pembelajaran yang inovatif diharapkan dapat meningkatkan hasil belajar dari peserta didik.

\section{METODE PELAKSANAAN}


Sasaran dalam pengabdian kepada masyarakat adalah peserta didik kelas V di SD Negeri 3 Pasarbatang kabupaten Brebes provinsi Jawa Tengah. Sekolah ini tergolong dalam kategori sekolah ramah anak dan memiliki banyak peserra didik. Sekolah ini menjadi pilihan dikarenakan peserta didik tersebut, memiliki kendala dalam permasalah minat belajar dan motivasi terutama dalam pembelajaran matematika. Kreativitas penggunaan media pembelajaran juga dibutuhkan oleh peserta didik dalam keberlangsungan proses kegiatan belajar mengajar.

Tahapan pelaksanaan pengabdian masyarakat diawali dengan adanya observasi awal dalam kegiatan sosialisasi, dimana dilihat dari masalah yang ada dilapangan. Kemudian dilanjutkan dengan kegiatan sosialisasi pemanfaatan media jam sudut dalam pembelajaran SD. Sosialisasi diberikan pada peserta didik dan diberikan arahan terkait dengan media tersebut. Setelah itu, kegiatan dilihat dengan perkembangan pengetahuan, sikap, tingkah laku dan keterampilan peserta didik terkait dengan pembelajaran.

Proses pengabdian masyarakat dilakukan pada bulan Februari 2021. Teknik analisis yang digunakan dalam penelitian ini adalah ceramah, diskusi dan dokumentasi. Ceramah digunakan untuk memberikan arahan terkait dengan media jam sudut, yangmana dengan menggunakan materi pembelajaran SD. Diskusi dilakukan setelah adanya kegiatan sosialisasi melalui ceramah mengenai jam sudut. Kemudian dokumentasi digunakan untuk mendokumentasi kegiatan sosialisasi, baik berkaitan dengan foto maupun data hasil belajar peserta didik.

Hasil

\section{HASIL DAN PEMBAHASAN}

Hasil kegiatan sosialisasi pemanfaatan media jam sudut dalam pembelajaran SD. Kegiatan dilaksanakan di SD Negeri Pasarbatang 03. SD Negeri Pasarbatang 03 termasuk dalam katergori sekolah ramah anak. Hal ini dapat terlihat pada kondisi lingkungan di SD tersebut. Gambar 1 dapat ditunjukkan halaman depan lokasi kegiatan sosialisasi.

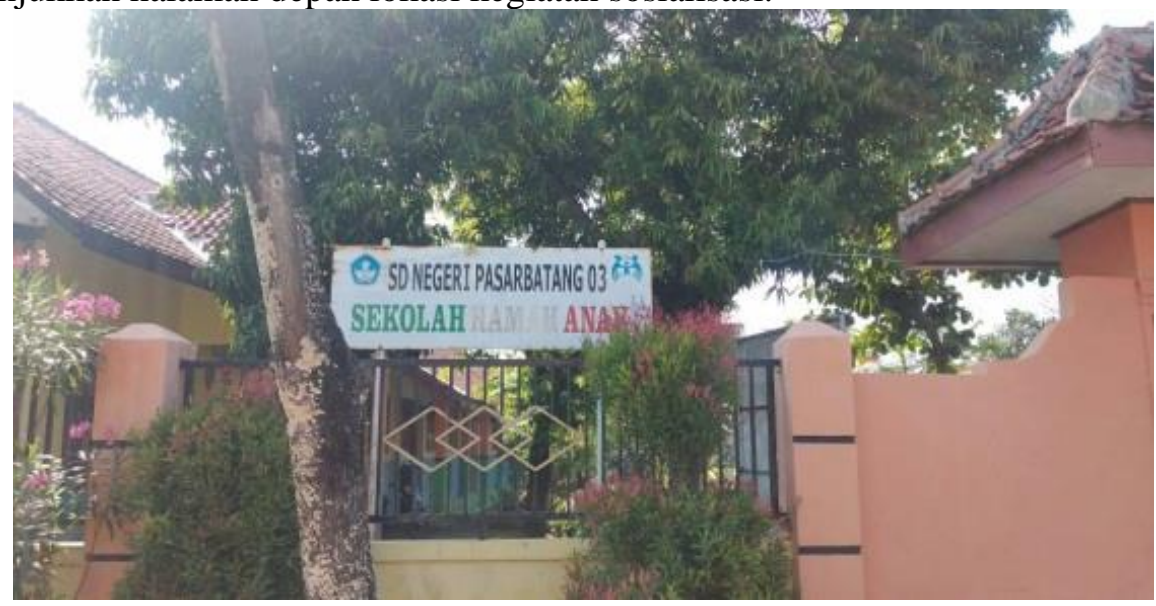

Gambar 1. Halaman depan SD Negeri Pasarbatang 03

Hasil kegiatan dapat ditunjukkan sebagai berikut. Kegiatan pemanfaatan media jam sudut dalam pembelajaran SD dapat dilihat pada Gambar 2. Pada gambar terlihat bahwa peserta didik memanfaatkan media pembelajaran dengan baik. Dengan adanya media tersebut, memudahkan bagi peserta didik dalam menerima materi sudut. Peserta didik diajarkan beberapa sudut dalam pembelajaran. 


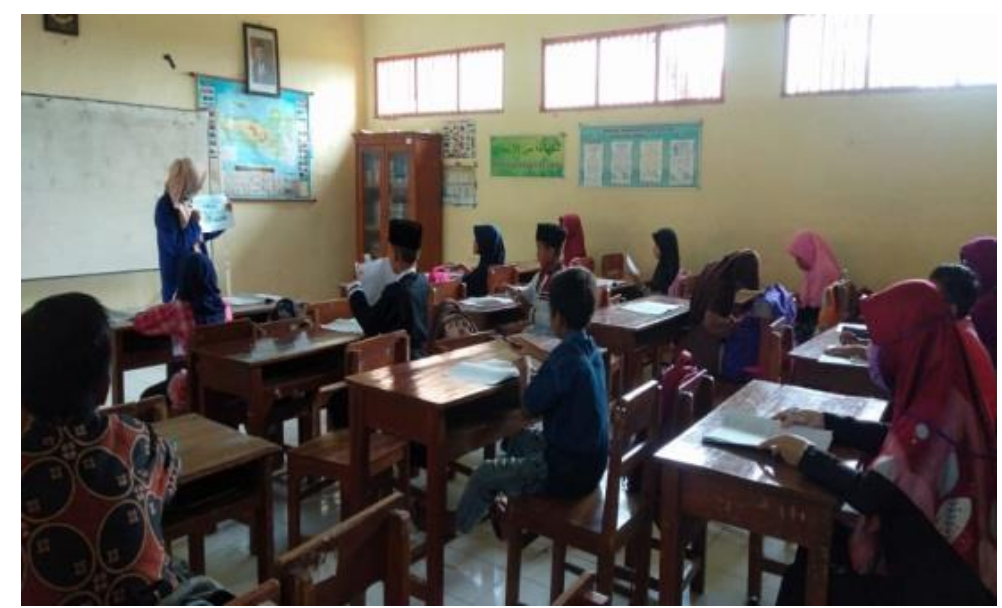

Gambar 2. Pemanfaatan media jam sudut

Perilaku peserta didik dalam penggunaan media jam sudut sangat menyenangkan dan materi yang disampaikan mudah untuk dipahami. Dengan adanya hal tersebut, peserta didik terlihat antusias dalam pembelajaran. Peserta didik dapat memahami materi sudut $90^{\circ}, 180^{\circ}$ dan $360^{\circ}$. Kegiatan tersebut, tampak pada Gambar 3.

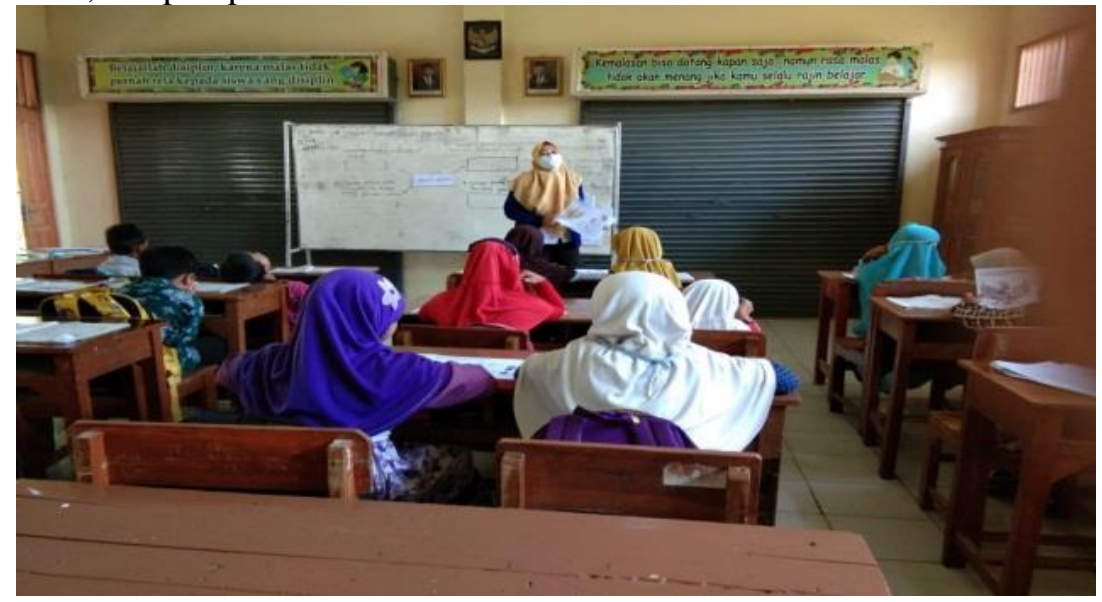

Gambar 3. Peserta didik terlihat antusias dalam pembelajaran

Hasil dapat ditunjukkan bahwa peserta didik dapat memahami sudut siku-siku $\left(90^{\circ}\right)$, sudut lancip $\left(90^{\circ}\right)$ dan sudut tumpul $\left(180^{\circ}\right)$. Hal ini juga dapat ditunjukkan ketika peserta didik ketika melihat dan memahami jam dinding. Peserta didik dapat membedakan sudut tersebut dalam memahami pukul berapa jam ditunjukkan. Sehingga memudahkan peserta didik dalam memahami menerima materi yang ada.

\section{Pembahasan}

Hasil dari kegiatan sosialisasi menunjukkan bahwa dengan adanya media pembelajaran hasil belajar peserta didik menjadi lebih baik. Media yang disampaikan guru dapat diterima oleh peserta didik. Dan materi yang disampaikan menjadi lebih menyenangkan. Hal ini sejalan dengan pernyataan bahwa media pembelajaran akan menjadi lebih efektif dan efisien apabila guru dapat memanfaatkan dan menggunakannya dengan baik. Hal ini sesuai bahwa pembelajaran jam sudut akan efektif dan efisien jika guru mampu menggunakan media dengan maksimal (Suharti Kadar, 2020).

Kegiatan juga ditunjukkan dengan adanya media jam sudut dalam pembelajaran di kelas. Jam sudut dapat dimanfaatkan oleh peserta didik SD pada kelas tinggi. Pernyataan menunjukkan bahwa media jam sudut dapat meningkatkan hasil belajar peserta didik. Hal ini dengan 
ditujukan adanya media jam sudut pada pembelajan matematika di Sekolah Dasar (Juma'atin, 2018).

Pembelajaran yang dilakukan dengan menggunakan media jam sudut terlihat menyenangkan, sehingga anak lebih antusias dalam menerima materi pembelajaran yang ada. Media pembelajaran dapat diterima oleh peserta didik dalam memahami materi yang ada. (Novi Mayasari, 2019) Pengembangan media pembelajaran dengan menggunakan media sudut dapat dikatakan menyenangkan. Sehingga kegiatan pembelajaran dapat dikatakan berjalan dengan lancar, tepat waktu dan kondusif.

Pembelajaran yang inovatif dapat meningkatkan motivasi belajar peserta didik, sehingga kegiatan pengabdian ini dapat berjalan dengan baik. Hal ini ditunjukkan dengan adanya pembelajaran dengan menggali sikap kreatif melalui media jam sudut dapat dikatakan baik. Dengan adanya jam sudut maka penilaian terkait dengan sikap dan keterampilan dapat terlihat, bukan hanya dilihat dari sisi kognitifnya saja.

Kreativitas pengajar dalam pembelajaran dibuthkan dalam mengelola kelas. Penggunaan media yang tepat dalam pembelajaran akan memudahkan peserta didik dalam belajar. Kreativitas yang terlihat rapi akan menyenangkan bagi peserta didik dalam meningkatkan kegiatan belajar mengajar. (Mega \& Yuliningsih, 2020) Media jam sudut dapat menggali sikap kreatif siswa.

Pengembangan media pembelajaran jam sudut elektrik untuk siswa kelas IV SD Negeri Pangeranan 3 Bangkalan dapat dikatakan efektif dan sangat menarik (Winda Berlyana Permatasari, 2018). Pengembangan media jam sudut dapat dikatakan valid dan sesuai dengan pembelajaran. Jadi, dapat dikatakn kegiatan pengabdian masyarakat ini dapat diterima oleh peserta didik kelas IV SD Negeri Pasarbatang 03 kecamatan Brebes.

Sasaran dalam pengabdian pada peserta didik kelas IV, dimana lebih ditekankan pada muatan pelajaran matematika. Hal ini dikarenakan materi yang akan disampaikan sesuai dengan jam sudut dan angka-angka yang ditampilkan akan terlihat dalam menganalisis. Peningkatan dengan menggunakan alat peraga jam sudut hasil belajar matematika dapat dikatakan meningkat (Putri, 2020).

Hal ini juga sejalan dengan yang telah dilakukan oleh (Nisak, 2015) Penilaian jam sudut dapat dimanfaatkan dalam pembelajaran di SD N Pendem. Hal ini dapat dinyatakan bahwa adanya peningkatan hasil belajar dan layak untuk digunakan dalam pembelajaran di sekolah. Berkaitan dengan hal tersebut, berarti kegiatan yang telah dilakukan dapat dikatakan lancar.

\section{KESIMPULAN}

Kesimpulan dalam kegiatan sosialisasi pemanfaatan media jam sudut dalam pembelajaran di SD dapat berjalan dengan baik dan lancar. Hal ini ditunjukan dengan adanya antusias peserta didik dalam mengikuti arahan dalam pemanfaatan media jam sudut tersebut. Peserta didik tertarik dan senang dalam menggunakan media yang telah disediakan, sehingga memudahkan peserta didik dalam memahami materi pembelajaran. Pembelajaran yang diterima oleh peserta didik terlihat adanya interaksi antara kedua belah pihak, yaitu penyaji materi dengan peserta didik. Peningkatan pembelajaran dapat terlihat pada peserta didik, hal ini ditunjukkan pada ranah sikap, keterampilan dan pengetahuan. Ketiga ranah tersebut dapat dilalui oleh peserta didik dalam pembelajaran di kelas. Pengelolaan kelas yang diterima juga terlihat lebih rapi dan dapat dengan mudah diterima oleh peserta didik.

\section{DAFTAR PUSTAKA}

Juma'atin. (2018). Pengembangan Media Pembelajaran Berbentuk Jam Sudut untuk 
Meningkatkan Hasil Belajar Siswa Materi Pengukuran Sudut Mata Pelajaran Matematika Kelas IV di MI Miftahul Huda Karangploso. In Energies (Vol. 6, Issue 1). http://journals.sagepub.com/doi/10.1177/1120700020921110\%0Ahttps://doi.org/10.1016/j .reuma.2018.06.001\%0Ahttps://doi.org/10.1016/j.arth.2018.03.044\%0Ahttps://reader.elsev ier.com/reader/sd/pii/S1063458420300078?token=C039B8B13922A2079230DC9AF11A 333E295FCD8.

Kurniawan, P. Y., Nurpratiwiningsih, L., Rahayu, T., \& Fitri, N. (2021). Pelatihan Menulis Deskripsi dengan menggunakan Media Gambar untuk Menumbuhkan Nilai-Nilai Karakter. JAMU: Jurnal Abdi Masyarakat, 1(02), 37-43.

Mega, \& Yuliningsih. (2020). Penggunaan Media Jam Sudut Pada Mata Pelajaran Matematika Kelas V SDN Ngesrep 03 Semarang Sebagai Media Pendahuluan Matematika.

Nisak, N. R. K. (2015). Pengembangan Media Pembelajaran Jam Sudut (Jadut) untuk Meningkatkan Kualitas Pembelajaran Jenis dan Besar Sudut pada Kelas III Sekolah Dasar. In Universitas Muammadiyah Malang.

Novi Mayasari, dkk. (2019). Pemanfaatan Media Pembelajaran Jam Sudut dalam Pembelajaran Matematika di SD. 3(1), 81-88.

Putri, A. D. (2020). Peningkatan Hasil Belajar Matematika dengan Menggunakan Alat Peraga Jam Sudut pada Peserta Didik kelas IV SDN 2 Sunur Sumatera Selatan. Jurnal Pendidikan Dan Pembelajaran Dasar, 4(1), 274-282.

Suharti Kadar. (2020). Penggunaan Media Jam Dinding pada Pokok Bahasan Pengukuran Sudut pada Siswa Kelas IV Sekolah Dasar. Seminar Nasional Pendidikan Matematika, 811-816.

Winda Berlyana Permatasari, D. (2018). Pengembangan Media Pembelajaan Jam Sudut Elektrik untuk Siswa kelas IV SD negeri Pangeran 3 Bangkalan. Widyagogik, 6(1), 73-79. 